\title{
Comparison between the Counter Immunoelectrophoresis Test and Mouse Neutralization Test for the Detection of Antibodies against Rabies Virus in Dog Sera
}

\author{
Luzia Helena Queiroz da Silva+, César Eduardo Bissoto ${ }^{++}$, Cristiano de Carvalho, \\ Tereza Cristina Cardoso, Devani M Pinheiro, Silvia Helena Venturoli Perri
}

\author{
Departamento de Apoio, Produção e Saúde Animal, Curso de Medicina Veterinária, Unesp, Rua Clóvis Pestana 793, \\ 16050-680 Araçatuba, SP, Brasil
}

\begin{abstract}
The detection of rabies antibodies is extremely valuable for epidemiological studies, determination of immune status in man, animals, and for the diagnosis of the disease. Several serological procedures have been described for this purpose. The present study reports a comparison between counterimmunoelectrophoresis test (CIET) and mouse neutralization test (MNT) in the detection of antibodies against rabies virus from 212 serum samples of vaccinated dogs. The agreement between both techniques was $79.7 \%$ and a significative association was demonstrated. The correlation coefficients between MNT and the CIET titers was determined considering 88 samples showing positive results in both techniques [CIET $=2$ and $M N T=5(0.13 \mathrm{IU} / \mathrm{ml})]$ and resulted $r^{2}=0.7926(p<$ 0.001). The performance of CIET system was technically simple, cheap and rapid, and thereby it could be useful for serological monitoring of dog vaccination campaigns as well as for individual analysis.
\end{abstract}

Key words: rabies - rabies antibodies - mouse neutralization test - counterimmunoelectrophoresis test

The most effective way to control rabies is the vaccination of dogs still the most important reservoirs of the disease in several parts of the world. In fact, the resistance to rabies virus infection induced by vaccination is associated with neutralizing antibody production and many procedures have been described for detecting or measuring those antibodies. Mouse neutralization test (MNT), developed by Atanasiu (1967) was used for many years as a standard virus neutralization test which was substituted by microneutralization tests in cell culture as rapid fluorescent-focus inhibition test (RFFIT), developed by Smith et al. (1973), and more recently the fluorescent antibody virus neutralization test (FAVN test) developed by Cliquet et al. (1998).

In 1977 a modified counterimunoelectrophoresis (CIE) technique has been developed for determining rabies antibodies and was described as a sensitive, simple, inexpensive and relatively rapid procedure (Diaz \& VarelaDiaz 1977). The method provided results that correlated well with those obtained by the MNT, the indirect fluorescent-antibody test and the RFFIT (Diaz \& Myers 1980, 1981, Diaz 1983). The technique was also used to determine the antigens content in lots of suckling mouse rabies and tissue culture rabies vaccines (Miceli et al. 1992, 1993), and to determine the antibody titer in hyperimune antirabies sera used for human prophylactic treatment (Diaz \& Myers 1984). Initially developed to determine rabies

Financial support by Fundunesp (Proc. 566/92-DFP/F/CAV) ${ }^{+}$Corresponding author. Fax: +55-18-622.6487. E-mail: lhqsilva@fmva.unesp.br

++Veterinary student - PIBIC/CNPq fellowship

Received 25 April 2001

Accepted 9 October 2001 antibodies in human sera (Diaz \& Varela-Diaz 1977, Diaz et al. 1986, Chauhan et al. 1991) it was also used for equine (Diaz \& Myers 1984, Diaz et al. 1995), bovine (Albas et al. 1995b, Oliveira et al. 2000), ovine (Sanchez \& Rubio 1991), and canine sera (Albas et al. 1995a). The present study reports a comparison between counterimmunoelectrophore-sis test (CIET) and mouse neutralization test in the detection of antibodies against rabies virus in sera of dogs immunized along vaccination campaigns.

\section{MATERIALS AND METHODS}

Dogs sera and vaccination procedure - Serum samples $(\mathrm{n}=212)$ were obtained from 16 non-vaccinated dogs and from 67 vaccinated with $2 \mathrm{ml}$ of Fluenzalida's type vaccine (inactivated suckling mouse brain vaccine) by subcutaneous administration during vaccination campaigns. In order to obtain different level of antibody titers, blood samples were taken from dogs that received different number of vaccine doses during their lifetime and also at different periods of vaccination: one, six, nine and twelve months.

CIE antigen and indicator serum - The strain used was the Challenge Virus Standard (CVS 31/2) obtained from Instituto Biológico, São Paulo, Brazil, passed twice in suckling mouse brain. The antigen was prepared in suckling mouse brain and the indicator serum was produced by the immunization of rabbits with the rabies vaccine according to the procedures established by Diaz (1985).

CIET - The CIET was performed essentially by the procedure described by Diaz (1985). In brief, serial of two-fold dilution beginning from 1:5 to 1:40 was prepared. An equal volume of fixed dilution (1:40) of antigen, determined by chessboard procedure, was added to each dilution of dog sera and incubated for $37^{\circ} \mathrm{C}$ for $60 \mathrm{~min}$. After 
that, the serum-virus mixture in the cathode wells was electrophoresed in agarose gel at $0.9 \%$ at a constant current of $10 \mathrm{~mA}$ per slide during $45 \mathrm{~min}$. Following, the anodal wells were filled with indicator serum (1:4) and further electrophoresed for $120 \mathrm{~min}$ at the same current. Negative and standard positive controls were tested simultaneously in each run. The slides were maintained overnight in phosphate buffer saline (PBS) and the precipitin bands were observed with oblique lighting as well as stained with amido black. The highest dilution of each serum showing no precipitation line was taken as endpoint and the titer was expressed as the reciprocal of the dilution.

$M N T$ - Serial five-fold dilution of the test and standard sera were made in a PBS pH 7.3. To $0.4 \mathrm{ml}$ of diluted serum an equal amount of CVS (challenge virus standard) strain, containing $30-50 \mathrm{LD}_{50} / 0.03 \mathrm{ml}$ was added, and the mixture incubated at $37^{\circ} \mathrm{C}$ for $90 \mathrm{~min}$. Each dilution of the serumvirus mixture was inoculated intra-cerebrally into each group of six mice of either sex. After an observation period of 15 days, the titer was determined by the ReedMüench method (Reed \& Müench 1938). An international reference serum (WHO Standard for Rabies Immunoglobulin from National Institute for Biological Standard and Control) containing $30 \mathrm{IU} / \mathrm{ml}$ was used to calculate the titers in IU (International Units)/ml.

Statistical analysis - For the purposes of statistical analysis MNT titers were expressed as $\log _{5}$ of the reciprocals and CIET titers as $\log _{2}$ of the reciprocals. The Pearson linear correlation coefficient $(r)$ between two variables was determined considering 88 samples showing positive results in both techniques [CIET $=2$ and MNT $=5(0.13 \mathrm{IU} / \mathrm{ml})]$ and the regression analysis was used to fit a straight line throughout a set of points. The chisquare test was used to check for an association between the titers obtained by both techniques $(n=212)$.

\section{RESULTS}

The positive and negative results were determined with the cutoff bring as $\geq 2$ for CIET and $\geq 5(0.13 \mathrm{IU} / \mathrm{ml})$ for MNT. Table I shows the co-specificity (83.5\%) and cosensitivity $(76.5 \%)$ of CIET for antibody detection. Table II shows in details, the frequency distribution of results according to the antibodies titer in each test, expressed as IU/ml (MNT) and the reciprocals of serum dilution as described before for CIET. The agreement between CIET

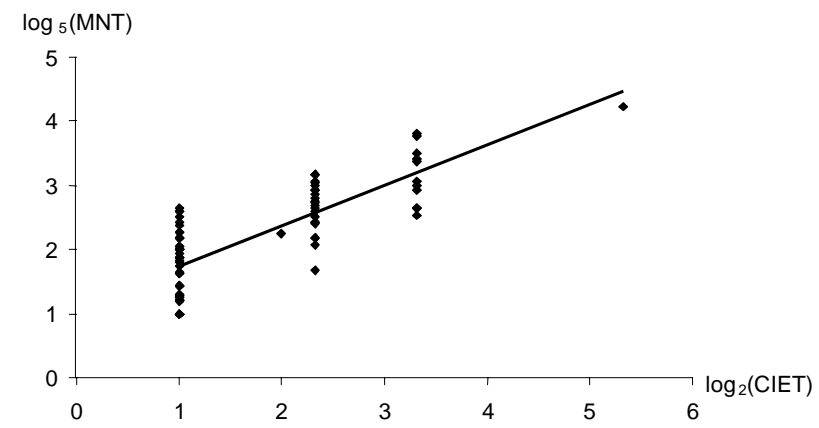

Linear regression line for antibody titers obtained by mouse neutralization test-MNT $\left(\log _{5}\right)$ and by counterimmunoelectrophoresis test-CIET $\left(\log _{2}\right) ; \mathrm{y}=1.102839+0.631282 \mathrm{x} ; r=0.7926$

\section{TABLE I}

Comparative results of the counterimmunoelectrophoresis test (CIET) and mouse neutralization test (MNT) for determining rabies antibodies in vaccinated dogs sera

\begin{tabular}{lccc}
\hline & \multicolumn{3}{c}{ MNT } \\
\cline { 2 - 3 } CIET & Positive & Negative & Total \\
\hline Positive & 88 & 16 & 104 \\
Negative & 27 & 81 & 108 \\
\hline Total & 115 & 97 & 212 \\
\hline
\end{tabular}

Co-specificity $=83.5 \%$; Co-sensitivity $=76.5 \%$; Agreement $=$ $79.7 \% ; \chi^{2}=75.865(\mathrm{p}<0.0001)$

and MNT was $79.7 \%$ and a significative association between them at $0.01 \%$ of probability $\left(\chi^{2}=75.865\right)$ was demonstrated. The correlation coefficient between the CIET and the MNT for a total of 88 serum samples positive in both techniques was $r=0.7926$ ( $\mathrm{P}<0.001$ ). The linear regression equation that resulted on the straight line given in the Figure was $y=1.1028+0.6313 x$ indicating the minimum estimated MNT value which corresponds to a certain CIET/MNT titer.

\section{DISCUSSION}

Dog sera had already been studied by Diaz and VarellaDiaz (1977) in their original description of the CIET for detection of antibodies to rabies virus and by Albas et al. (1995a). In most of the experiments developed to have

TABLE II

Frequency distribution for results of antibodies titer obtained by the counterimmunoelectrophoresis test (CIET) and mouse neutralization test (MNT) in sera of vaccinated dogs

\begin{tabular}{lccccrr}
\hline & \multicolumn{5}{c}{ MNT titer ${ }^{a}$} \\
\cline { 2 - 7 } CIET titer $^{b}$ & $<0.13$ & $0.13-0.62$ & $0.63-3.12$ & $3.15-15.62$ & $>15.62$ & Total \\
\hline$<2$ & 81 & 27 & 0 & 0 & 0 & 108 \\
$2-4$ & 13 & 38 & 15 & 0 & 0 & 66 \\
$5-10$ & 3 & 1 & 22 & 0 & 1 & 36 \\
$20-40$ & 0 & 67 & 37 & 10 & 1 & 212 \\
\hline Total & 97 & 1 & 0 & & 0 \\
\hline
\end{tabular}

$a$ : titers expressed as $\mathrm{IU} / \mathrm{ml} ; b$ : titers expressed as reciprocals of serum dilutions 
those antibodies evaluated, both in human and animal sera, the correlation coefficient ranged from $r=0.58$, in humans (Diaz \& Myers 1980) to $r=0.85$ in ovine (Sanchez $\&$ Rubio 1991) and $r=0.91$ in bovine (Albas et al. 1995b). Albas et al. (1995a) obtained a correlation coefficient $r=$ 0.76 for dog sera which was very similar to the results observed in the present study $(r=0.79)$. According to Sanchez and Rubio (1991) the original description of the CIET mentioned that a correlation coefficient equal or superior to 0.70 indicates an acceptable association.

Positive results was established as those higher than 5 in the MNT, that corresponded to $0.13 \mathrm{IU} / \mathrm{ml}$. The protective titer of $0.5 \mathrm{IU} / \mathrm{ml}$ recommended by WHO corresponded in our experiments to a titer of 20 (reciprocal of dilution). The titer in IU/ml was not established for the CIET. All the 16 non-vaccinated dogs showed negative results in both CIE and MN tests. From the 27 sera showing negative results in CIET and positive results in MNT, $52 \%(14 / 27)$ presented the minimum considered titer for the experiment $(0.13 \mathrm{IU} / \mathrm{ml}), 37 \%(10 / 27)$ titers from $6(0.15$ $\mathrm{IU} / \mathrm{ml})$ to $10(0.25 \mathrm{IU} / \mathrm{ml})$ and $11 \%(3 / 27)$ from $11(0.27 \mathrm{IU} /$ $\mathrm{ml})$ to $25(0.62 \mathrm{IU} / \mathrm{ml})$ (data not shown on the Tables).

The above mentioned studies did not describe the values obtained for sensitivity, specificity and agreement of CIET in comparison to MNT but most of the results showed a specificity higher than the sensitivity (Diaz \& Myers 1980). Using a higher number of serum samples (n $=212$ ) and comparing the CIET with the MNT (standard test) the results of this experiments also showed higher values for CIET specificity compared to sensitivity.

Although other recent techniques, as efficient and quick as CIET, could be used for measuring antibody titers to rabies virus (Piza et al. 1999), CIET is described as measuring antibodies directed to the viral glycoprotein and consequently detecting the neutralizing potential of the studied sera (Diaz \& Myers 1981). The CIET has the advantages of being a relatively simple, quick and economical method compared to MNT and other methods like RIFFT (Smith et al. 1973) and FAVNT (Cliquet et al. 1998). Furthermore, it could be useful for the evaluation of antibody titer in dog population after massive vaccination campaigns and because of its higher specificity, it might also be useful to individual analysis.

\section{ACKNOWLEDGEMENTS}

To Dr Avelino Albas (Biological Institute, Regional of Presidente Prudente) for helpful contributions.

\section{REFERENCES}

Albas A, Camargo LM, Giometti J, Tarumoto MH 1995a. Avaliação de soros de cães imunizados contra a raiva pelo método de contraimunoeletroforese - CIE. Rev Med Vet Zoot UNESP São Paulo 7: 99-105.

Albas A, Pardo PE, Rinaldi PLF, Tarumoto MH 1995b. Avaliação do método de contraimunoeletroforese para titular soros de bovinos vacinados contra a raiva. Rev Med Vet Zoot UNESP São Paulo 7: 141-145.

Atanasiu P 1967. Titrage des anticorps rabiques pratiqué sur les sérums humaines. Bull Off Int Épizoot 67: 383-387.
Chauhan A, Sood DK, Saha SM, Kapoor M, Aggarwal RK, Saxena SN 1991. The quantitation of rabies-specific antibodies III. A comparative evaluation of modified counterimmunoelectrophoresis, haemagglutination inhibition and serum neutralization titres of humana sera. Biologicals 19: 103-106.

Cliquet F, Aubert M, Sagnè L 1998. Development of a fluorescent antibody virus neutralisation test (FAVN test) for the quantification of rabies-neutralizing antibody. J Immunol Methods 212: 79-87.

Diaz AM 1983. Rabies neutralizing antibodies determination by the modified counterimmunoelectrophoresis test and the rapid fluorescent focus inhibition test. Ztb Bakt Mikrobiol Hyg (A) 256: 1-6.

Diaz AM 1985. Técnica de Contrainmunoelectroforesis para el Diagnóstico Serológico de la Rabia, Centro Panamericano de Zoonosis, Série de Monografias Cientificas y Tecnicas $\mathrm{n}^{\circ}$ 13, Ramos Mejia, Buenos Aires.

Diaz AM, Myers DM 1980. Determination of serum neutralization antibodies to rabies virus by a modified counterimmunoelectrophoresis test. J Clin Microbl 12: 175-179.

Diaz AM, Myers DM 1981. Comparison between a modified counterimmunoelec-trophoresis test and the indirect fluorescent antibody for detection of antibodies to rabies virus in human sera. J Clin Microb 14: 446-448.

Diaz AM, Myers DM 1984. Evaluation of hyperimmune rabies sera by the counterimmunoelectrophoresis test. J Biol Stand 12: 61-65.

Diaz AM, Arispe E, Brunel C, Cavandoli C, Dellepiane N, Miranda A 1986. La tecnica de contrainmunoelectroforesis para la determinación de anticuerpos antirrabicos. Bol Of Sanit Panam 101: 255-262.

Diaz AM, Valentini EJG, Albas A, Fuches RMM, Gallina NMF 1995. Hyperimmune antirabies sera titration by standard mouse neutralization and counterimmunoelectrophoresis tests, comparing results of different laboratories. Rev Inst Med Trop São Paulo 37: 435-440.

Diaz AMO, Varela-Diaz VM 1977. The counterimmunoelectrophoresis test for detection of antibodies to rabies virus. Ann Microbiol 128-A: 331-337.

Miceli G, Terroba JE, Diaz AM 1993. Evaluación de la tecnica de contrainmunoelectroforesis para determinar la potencia antigenica de las vacunas antirrabicas. Rev Inst Med Trop São Paulo 35: 543-550.

Miceli GS, Silva JS da, Bonetto D, Diaz AM 1992. Valuation of the counterimmunoelectrophoresis tecnique for in-process control of rabies vaccines. Arq Biol Tecnol 35: 659-665.

Oliveira AN, Andrade MCR, Silva MV, Moura WC, Contreiras EC 2000. Immune response in cattle vaccinated against rabies. Mem Inst Oswaldo Cruz 95: 83-88.

Piza AST, Santos JLF, Chaves LB, Zanetti CR 1999. An ELISA suitable for the detection of rabies virus antibodies in serum samples from human vaccinated with either cell-culture vaccine or suckling-mouse-brain vaccine. Rev Inst Med Trop São Paulo 41: 39-43.

Reed LJ, Müench H 1938. A simple method of estimating fifty percent endpoints. Am J Hyg 27: 493-497.

Sanches PM, Rubio EL 1991. Titulación de anticuerpos antirrabicos de sueros ovinos mediante las tecnicas de contrainmunoelectroforesis y soroneutralización. Tec Pec Mex 29: 165-168.

Smith JS, Pamela AY, George MB 1973. A rapid reproducible test for determining rabies neutralizing antibody. Bull $\mathrm{WHO}$ 48: 535-541. 
Serology for Rabies Antibodies in Dog Sera • Luzia Helena Queiroz da Silva et al. 